\title{
Histological and steroidogenic changes in dominant ovarian follicles during oestradiol-induced atresia in heifers
}

\author{
Christopher R Burke ${ }^{1,2}$, Horacio Cárdenas ${ }^{1}$, Martin L Mussard ${ }^{1}$ and Michael L Day ${ }^{1}$ \\ ${ }^{1}$ Department of Animal Sciences, The Ohio State University, Columbus, Ohio 43210, USA and ${ }^{2}$ Dexcel Ltd, \\ Private Bag 3221, Hamilton, New Zealand \\ Correspondence should be addressed to M L Day, 2027 Coffey Rd, Columbus, OH 43210, USA; Email: Day.5@osu.edu
}

\begin{abstract}
Histological and steroidogenic changes within dominant ovarian follicles (DFs) undergoing atresia following systemic administration of oestradiol benzoate (ODB) were characterized in beef heifers. At $5.6 \pm 0.1$ days after the onset of oestrus, heifers received $1 \mathrm{mg}$ ODB i.m./500 $\mathrm{kg}$ body weight $(O D B ; n=15)$ or served as controls $(n=15)$. Timing of treatment initiation was designated as hour (h) 0 on day (d) 0 , and coincided with the presence of the DF of the first follicular wave (DF1). Within treatments, the DF1 was collected following ovariectomy in four animals at $h \mathbf{1 2}, \mathrm{h} 36$ or after ultrasonic detection of a new wave (NW) of ovarian follicular development. In heifers of the NW groups ( $n=7$ per treatment), blood samples were collected at intervals of $20 \mathrm{~min}$ for $12 \mathrm{~h}$ beginning at $\mathrm{h}-12,0,24$ and 48 to characterize circulating LH patterns. Administration of ODB suppressed $(P<0.01)$ mean concentrations of LH at $h 24$ and $h 48$ by preventing $(P<0.05)$ the increase in $\mathrm{LH}$ pulse amplitude observed in controls, but had no effect on FSH. Follicular fluid (FF) concentrations of androgens and oestradiol were reduced at $h \mathbf{3 6}$ in the ODB-treated group. The diameter of the DF1 and the number of granulosa cell layers were also reduced in ODB-treated as compared with control heifers. Treatment differences were not observed in the proportion of apoptotic granulosa cells as assessed using the TUNEL assay method, and timing of a new wave of follicular development (d 4.6 \pm 0.2$)$ was similar $(P>0.1)$ among treatments. A prominent characteristic of oestradiol-induced atresia of the DF1 of the oestrous cycle in heifers was a loss in oestrogenic function associated with reduced LH support. However, the timing of new follicular development may be influenced by a factor(s) other than the status of the DF undergoing oestradiol-induced atresia. Reproduction (2005) 129 611-620
\end{abstract}

\section{Introduction}

Strategic regulation of ovarian follicular development is an important component in the application of cattle reproductive technologies such as oestrous synchronization and embryo transfer (Bo et al. 2002). One approach to control follicular development in a group of cattle is to synchronously induce atresia of the dominant follicles (DFs). Removal of the functional DF causes an increase in follicle-stimulating hormone (FSH) that drives recruitment of a new cohort of follicles (Adams et al. 1992, Bergfelt et al. 1994). Oestradiol-17ß (Bo et al. 1995) or conjugated forms of oestradiol (Thundathil et al. 1998, Day \& Burke 2002) have been used effectively for this purpose. The current limitations to this approach include variability in responses associated with the stage of follicular development when oestradiol is administered, and also the lack of precision in the timing of new follicular wave development (Diskin et al. 2002, Burke et al. 2003).

Induction of atresia in the DF is a prerequisite when using oestradiol to synchronize a new wave of follicular development. The developmental events occurring in DFs throughout their growth cycle have been reviewed in Fortune (1994) and Bao and Garverick (1998). In the early stages of atresia of DFs, a reduction in aromatase activity and oestradiol synthesis is observed (Price et al. 1995). Loss of oestrogenicity may (Badinga et al. 1992, Lucy et al. 1992) or may not (McNatty et al. 1984, Xu et al. 1995) be associated with a reduction in androgen precursors. In atretic DFs, the granulosa cell compartment is eroded, and there is a high incidence of pyknotic nuclei. Follicular fluid (FF) oestrogen content is low, while FF concentrations of progesterone are increased in atretic DFs (Price et al. 1995).

Follicular atresia in mammalian ovaries is facilitated by a 'programmed-cell death' process called apoptosis (Kaipia \& Hsueh 1997). During apoptosis, the nuclear DNA is fragmented by $\mathrm{Ca}^{2+} / \mathrm{Mg}^{2+}$-dependent endonucleases (Wyllie 1980). Cells containing fragmented DNA can be detected using the terminal deoxynucleotidyl transferase (TdT)-mediated dUTP nick-end labelling (TUNEL) procedure (Gavrieli et al. 1992). The ability of exogenous oestradiol to induce a new wave of follicular development 
in a synchronous fashion is documented in cattle (Bo et al. 2002, Burke et al. 2003). However, the underlying basis for the existing DF to lose dominance following administration of oestradiol in cattle has not previously been characterized.

The objectives of the present study were to characterize steroidogenic and cellular changes within the DF during loss of dominance and the associated changes in circulating gonadotrophins in response to administration of oestradiol benzoate (ODB). The model of oestradiol-induced atresia permits an evaluation of the temporal changes within the DF as dominance is relinquished to allow new follicular growth. An increased understanding of this process may lead to improved methods in manipulating ovarian follicular development during oestrous synchronization treatment.

\section{Materials and Methods}

Animal procedures used in these experiments were approved by The Ohio State University Agricultural Animal Care and Use Committee.

Oestrus was synchronized in 30 reproductively mature Simmental $\times$ Angus heifers weighing $462 \pm 38 \mathrm{~kg}$ (mean \pm S.D.) following one or two i.m. injections of prostaglandin $F_{2 \alpha}$ (PGF; Lutalyse, Pfizer, Kalamazoo, MI, USA). Behavioural oestrus was monitored using an electronic surveillance system (HeatWatch, DDx, Denver, CO, USA). Animals were allocated at $5.6 \pm 0.1$ days after the onset of oestrus to receive $1 \mathrm{mg} \mathrm{ODB} / 500 \mathrm{~kg}$ body weight (BW) by i.m. injection (ODB; CIDIROL, InterAg, Hamilton, New Zealand; $n=15$ ) or to serve as untreated controls $(C ; n=15)$. Treatments were given at this stage of the oestrous cycle as all animals were expected to have a clearly identifiable DF of the first follicular wave (DF1) after oestrus, and a functional corpus luteum. The timing of the ODB injection was designated as hour (h) 0 of day (d) 0. Diameter and location of corpora lutea and ovarian follicles $\geq 3 \mathrm{~mm}$ in diameter were monitored daily by transrectal ultrasonography using a $7.5 \mathrm{MHz}$ transducer probe (Aloka Co. Ltd, Tokyo, Japan) beginning within $24 \mathrm{~h}$ of oestrus being detected. Eight animals from each treatment were bilaterally ovariectomized at either $12 \mathrm{~h}(12 \mathrm{H})$ or $36 \mathrm{~h}(36 \mathrm{H} ; n=4$ per time point). The remaining seven heifers per treatment remained intact until emergence of a new wave of follicular development was detected (new wave; NW). The frequency of ultrasonography examinations increased to every $12 \mathrm{~h}$ from $\mathrm{h} 60$ in heifers of the NW group until emergence of a new follicular wave was detected. Emergence of a new follicular wave was defined as the day of appearance of a cohort of emerging follicles on the ovary of which at least one was $\geq 5 \mathrm{~mm}$ in diameter. Four heifers per treatment in the NW group were ovariectomized within $24 \mathrm{~h}(14.7 \pm 3.5 \mathrm{~h})$ of detection of a new wave of follicular development. The endpoint for the remaining three NW animals in each treatment was the same, but these were not ovariectomized. The experiment was conducted over two periods (period 1 and 2) 14 days apart. The number of heifer allocated to treatments was balanced within period $1(n=14)$ and period $2(n=16)$.

\section{Blood sampling}

Blood samples were collected daily from a jugular vein of all animals after detection of oestrus and then at $6 \mathrm{~h}$ intervals between $\mathrm{h}-12$ and ovariectomy, or until the emergence of a new follicular wave was confirmed. Blood was collected into glass tubes containing an anticoagulant (EDTA) and centrifuged at $1500 \mathrm{~g}$ for $12 \mathrm{~min}$. Plasma was harvested and stored at $-20^{\circ} \mathrm{C}$ until determination of FSH, progesterone and oestradiol. Serial blood collections from a jugular vein were performed in all heifers assigned to the NW treatment groups for determination of luteinising hormone (LH). A $4 \mathrm{ml}$ blood sample was taken at intervals of $20 \mathrm{~min}$ for periods of $12 \mathrm{~h}$ beginning at $\mathrm{h}-12$, 0,24 and 48 . Serial sampling was facilitated by placement of a 14-gauge indwelling catheter (Angiocath, BectonDickinson Infusion Therapy Systems, Inc., Sandy, UT, USA) into a jugular vein. A $2100 \mathrm{~mm}$ length of plastic tubing (Tygon, Norton Performance Plastics Co., Akron, OH, USA) with an internal diameter of $1.2 \mathrm{~mm}$ and overall capacity of $3 \mathrm{ml}$ was attached to the catheter using a modified 16-gauge needle inserted through an injection adaptor (Medex, Hilliard, OH, USA). Between the removal of each blood sample, the catheter line was flushed with sterile $3.5 \%$ sodium citrate $-0.9 \%$ sodium chloride solution containing an antibiotic $\left(2 \mathrm{mg} \mathrm{ml}^{-1}\right.$ oxytetracycline). The initial $7 \mathrm{ml}$ fluid withdrawn from the catheter were discarded while the following $4 \mathrm{ml}$ were retained as sample. Blood was collected into plastic tubes without anticoagulant and allowed to stand at $4{ }^{\circ} \mathrm{C}$ for about $42 \mathrm{~h}$ before centrifugation at $4750 \mathrm{~g}$ for $30 \mathrm{~min}$. Sera were harvested and stored at $-20^{\circ} \mathrm{C}$.

\section{Histology of the DF}

Following ovariectomy, the ovary bearing the DF1 was immediately placed into ice-cold sterile PBS for $3 \mathrm{~min}$. A sample of FF (approx. $150 \mu \mathrm{l}$ ) was collected and stored at $-20^{\circ} \mathrm{C}$. Within $10 \mathrm{~min}$ of ovariectomy, the DF1 was dissected out of the ovary and fixed in freshly prepared $4 \%$ paraformaldehyde-PBS ( $\mathrm{pH}$ 7.2) for about $24 \mathrm{~h}$ and embedded in Paraplast (Oxford Labware, Missouri, MO, USA) using routine procedures. The small volume of $\mathrm{FF}$ removed from the DF did not impede gross dissection of the DF from the ovary. Embedded DF1s were sliced into $8-\mu \mathrm{m}$ sections and mounted in groups of three to five consecutive sections on slides coated with aminoalkylsilane (Silane-Prep Slides, Sigma Diagnostics, St. Louis, MO, USA). The proportion of apoptotic cells in the granulosa cell compartment was determined by the TUNEL procedure using the ApoAlert DNA Fragmentation kit (Clontech Laboratories, Inc., Palo Alto, CA, USA) in accordance with the manufacturer's instructions. An anti-photo 
bleaching and nuclear counter-stain agent (DAPI, Vectashield, Vector Laboratories, Inc., Burlingame, CA, USA) was added as a final step to visualize granulosa cell nuclei. Each slide included a positive control section (DNase I-treated), the TUNEL section and a negative control section (TUNEL reaction buffer lacking TdT). Five fields within each follicle were evaluated by fluorescent microscopy at $\times 400$ magnification. Fields were chosen where the granulosa cell compartment was best visualized and was representative of the whole layer, and locations were spaced as evenly as possible around the follicle. The number of FITC $(510 \mathrm{~nm}$ emission wavelength)-labelled granulosa cells (apoptotic) was counted in each field and divided by the total number of nucleated granulosa cells (DAPI-stained; $430 \mathrm{~nm}$ emission wavelength). The average total number of cells counted per field in each DF of the six treatment groups are depicted in Table 1. An average value for percent apoptotic cells was calculated for each follicle. Most cells (>90\%) were FITC-labelled in positive controls and no labelling was observed in negative controls. The number of layers of granulosa cells was estimated visually in all fields by detection of DAPI-stained nuclei.

\section{Hormone RIAs}

Concentrations of $\mathrm{FSH}$ in plasma were determined in duplicate using a double-antibody RIA (Wolfe et al. 1992, Burke et al. 2003). The average intra-assay coefficient of variation $(\mathrm{CV})$ was $2.4 \%$ and the average inter-assay $\mathrm{CV}$ (four assays) was $11.9 \%$ for standard pools that contained 1.6 and $2.2 \mathrm{ng} \mathrm{ml}^{-1} \mathrm{FSH}$. The average sensitivity was $0.2 \mathrm{ng} \mathrm{ml}^{-1}$. Concentrations of $\mathrm{LH}$ in sera were determined in duplicate using a double-antibody RIA (Dyer et al. 1990). The average intra-assay CV was $2.9 \%$ and the average inter-assay CV (five assays) was $7.7 \%$ for standard pools containing 1.6 and $4.4 \mathrm{ng} \mathrm{ml}^{-1} \mathrm{LH}$. The average sensitivity was $0.13 \mathrm{ng} \mathrm{ml}^{-1}$.
Concentrations of progesterone in plasma were determined in duplicate using a double-antibody RIA (Anderson et al. 1996). The intra-assay CV was $3.4 \%$ and the inter-assay CV (three assays) was $14.9 \%$ for standard pools containing 1.4 and $6.9 \mathrm{ng} \mathrm{ml}^{-1}$ progesterone. The average sensitivity was $0.24 \mathrm{ng} \mathrm{ml}^{-1}$. Concentrations of progesterone in FF were determined using a kit (Progesterone Coata-Count, DPC, Los Angeles, CA, USA) as previously described (Burke et al. 2003). Validation for use in FF was performed. Parallelism was confirmed by comparing the slopes from serially diluted FF $(-0.72)$ with the standard curve $(-0.76)$ after natural log-logit transformation. Average recovery of progesterone across concentrations ranging from 2.2 to $7 \mathrm{ng} \mathrm{ml}^{-1}$ was $102 \%$. Follicular fluid was diluted $1: 10$ or $1: 100$ in Progesterone Zero Calibrator (DPC) before addition to the reaction tube. The intra-assay CV was $2.4 \%$ and the inter-assay CV (five assays) was $4.0 \%$ for standard pools containing 1.5, 2.6 and $10.1 \mathrm{ng} \mathrm{ml}^{-1}$ progesterone. The average sensitivity was $0.05 \mathrm{ng} \mathrm{ml}^{-1}$.

Concentrations of oestradiol in plasma were determined in duplicate using a double-extraction single-antibody RIA (Anderson et al. 1996). The antibody used (Dr N R Mason, Lilly Research Laboratories, Indianapolis, IN, USA) has a $71 \%$ cross-reactivity with ODB (Kesler et al. 1977). The same assay without ether extraction was used to determine oestradiol content in FF where samples were diluted $10^{2}, 10^{3}, 10^{4}$ and $10^{5}$ in assay buffer before addition to the reaction tube. For plasma analyses, the average intraassay CV was $2.7 \%$ and the inter-assay CV (11 assays) was $12.2 \%$ for standard pools containing 13.7 and $20.4 \mathrm{pg} \mathrm{ml}^{-1}$ oestradiol. For follicular fluid oestradiol, the inter-assay CV among five samples of FF with known concentrations ranging between 36.6 and $316 \mathrm{ng} \mathrm{m}^{-1}$ was $15.4 \%$. Average sensitivity of the assays was $1.0 \mathrm{pg} \mathrm{ml}^{-1}$.

Concentrations of testosterone in FF were determined in duplicate using a kit (Total Testosterone Coat-a-Count,

Table 1 Concentrations of steroid hormones in follicular fluid and histological characteristics of the granulosa cell compartment in the first dominant follicle collected at h $12(\mathrm{H} 12), \mathrm{h} 36(\mathrm{H} 36)$ or after the emergence of a new follicular wave (NW) in heifers treated with $1 \mathrm{mg}$ oestradiol benzoate (ODB) i.m./500 kg BW on day $5.6 \pm 0.1$ of the oestrous cycle (designated as hour 0), as compared with contemporary untreated controls.

\begin{tabular}{|c|c|c|c|c|c|c|}
\hline \multirow[b]{2}{*}{ Variable $^{a}$} & \multicolumn{3}{|c|}{ Control } & \multicolumn{3}{|c|}{ ODB treated } \\
\hline & $\mathrm{H} 12$ & $\mathrm{H} 36$ & NW & $\mathrm{H} 12$ & $\mathrm{H} 36$ & NW \\
\hline Observations $(n)$ & 1 & 3 & 3 & 4 & 4 & 4 \\
\hline \multicolumn{7}{|c|}{ Concentrations $\left(\mathrm{ng} \mathrm{ml}^{-1}\right.$ ) in follicular fluid } \\
\hline Oestradiol & 366 & $258 \pm 27^{b}$ & $28 \pm 18^{c}$ & $545 \pm 182$ & $49 \pm 4^{\mathrm{c}}$ & $1.3 \pm 1^{\mathrm{d}}$ \\
\hline Progesterone & 38 & $35 \pm 2^{\mathrm{b}}$ & $28 \pm 5^{\mathrm{b}}$ & $30 \pm 6$ & $23 \pm 4^{b}$ & $118 \pm 31^{\mathrm{c}}$ \\
\hline Testosterone & 5.2 & $2.7 \pm 1.3^{\mathrm{b}}$ & $1.3 \pm 0.6^{\mathrm{b}, \mathrm{c}}$ & $15.2 \pm 4.2$ & $0.2 \pm 0.1^{\mathrm{c}}$ & $1.5 \pm 0.4^{b}$ \\
\hline Androstenedione & 2.9 & $1.2 \pm 0.6^{\mathrm{b}, \mathrm{d}}$ & $2.0 \pm 0.6^{\mathrm{d}, \mathrm{e}}$ & $18.8 \pm 8.7$ & $0.2 \pm 0.1^{\mathrm{b}}$ & $3.5 \pm 1.2^{\mathrm{e}}$ \\
\hline \multicolumn{7}{|c|}{ Histological characteristics of granulosa cells } \\
\hline No. of layers ${ }^{f}$ & 8.8 & $11.1 \pm 1.9$ & $4.7 \pm 0.4$ & $11.0 \pm 1.7$ & $8.3 \pm 0.6$ & $2.1 \pm 0.6$ \\
\hline Total cells per field & 100 & $65 \pm 11$ & $47 \pm 6$ & $90 \pm 36$ & $68 \pm 7.3$ & $28 \pm 12$ \\
\hline$\%$ cells apoptotic ${ }^{\mathrm{g}}$ & 4.6 & $3.8 \pm 3.2$ & $25.0 \pm 6.2$ & $0.3 \pm 0.3$ & $1.9 \pm 1.8$ & $25.7 \pm 6.4$ \\
\hline
\end{tabular}

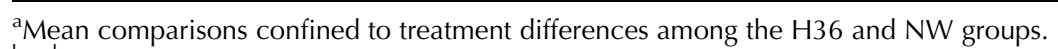

$\mathrm{b}, \mathrm{c}, \mathrm{d}, \mathrm{e}$ Means within rows with no common superscripts are different $(P<0.05)$.

${ }^{\mathrm{f}}$ Treatment $(P<0.05)$ and time $(P<0.01)$; see text.

${ }^{\text {g}}$ Time $(P<0.01)$; see text 
DPC). Parallelism was confirmed by comparing the slopes from serially diluted FF $(-0.79)$ with the standard curve $(-0.71)$ after natural log-logit transformation. Average recovery of testosterone across concentrations ranging from 0.4 to $6.8 \mathrm{ng} \mathrm{ml}^{-1}$ was $105 \%$. Follicular fluid samples were diluted 1:4 in Testosterone Zero Calibrator (DPC). The average intra-assay $\mathrm{CV}$ was $2.5 \%$ and the inter-assay CV (six assays) was $11.1 \%$ for standard pools containing $1.4,3.5$ and $9.7 \mathrm{ng} \mathrm{ml}^{-1}$ of testosterone. The average sensitivity was $0.03 \mathrm{ng} \mathrm{ml}^{-1}$. Concentrations of androstenedione in FF were determined in duplicate using a kit (Direct Androstenedione Coat-a-Count, DPC). The slope of serially diluted FF $(-0.89)$ was parallel with the standard curve $(-0.82)$, and average recovery of androstenedione across concentrations ranging from 1 to $3 \mathrm{ng} \mathrm{ml}^{-1}$ was 98\%. Samples of FF were diluted 1:4 in Androstenedione Zero Calibrator (DPC). The intra-assay CV (single assay) was $3.9 \%$ with a sensitivity of $0.1 \mathrm{ng} \mathrm{ml}^{-1}$.

\section{Statistical analyses}

Three of four DF1s in the $12 \mathrm{H} \mathrm{C}$ group were accidentally ruptured during ovariectomy. Thus, initial analyses of follicular data was confined to the $\mathrm{H} 36$ and NW groups in a $2 \times 2$ arrangement, and secondly to the $12 \mathrm{H} \mathrm{ODB}, 36 \mathrm{H}$ ODB and NW ODB treatment groups to test if the $12 \mathrm{H}$ ODB treatment differed from either the $36 \mathrm{H}$ ODB or NW ODB treatments. The interval from oestradiol treatment, or the equivalent time in controls, to maximal FSH concentrations was assessed in individual animals and these data are reported as the time of the $\mathrm{FSH}$ peak within treatment. The number of LH pulses, LH pulse amplitude and mean LH concentrations were determined as described by Goodman and Karsch (1980).

Data were analyzed by ANOVA using the MIXED procedure in SAS (SAS Institute Inc. 1996). A repeated measures model was used on any data collected from the same animal over consecutive time points. The repeated measures model was $\mathrm{Y}_{\mathrm{ijk}}=\mu+\mathrm{T}_{\mathrm{i}}+\mathrm{C}_{\mathrm{j}: \mathrm{i}}+\mathrm{H}_{\mathrm{k}}+(\mathrm{TH})_{\mathrm{ik}}+$ $e_{i j k}$ where $Y_{i j k}$ is the observation of the $j^{\text {th }}$ heifer in the $i^{\text {th }}$ treatment at the $k^{\text {th }}$ time, $\mu$ is the overall mean, $T_{i}$ is the fixed effect of the $i^{\text {th }}$ treatment, $c_{j: i}$ is the random effect of the $\mathrm{j}^{\text {th }}$ cow within the $\mathrm{i}^{\text {th }}$ treatment $\left(\mathrm{c}_{\mathrm{j}: \mathrm{i}} \sim \mathrm{N}\left[0, \sigma_{\mathrm{c}}^{2}\right]\right), \mathrm{H}_{\mathrm{k}}$ is the fixed effect of the $k^{\text {th }}$ time, $(\mathrm{TH})_{\mathrm{ik}}$ is the treatment by time interaction term, and $e_{i j k}$ is the random residual error effect $\left(e_{i j k} \sim N[0, \Sigma]\right)$, where $\Sigma$ is the variance-covariance structure of the residual errors with a first order autoregressive structure for repeated measurements within cows. The effect of experimental replication (period) was tested for all dependent variables and replication was included in the model if it was a significant $(P<0.05)$ source of variation. For analyses of FSH data, the pretreatment concentration of $\mathrm{FSH}$ (value at $\mathrm{h} 0$ ) within animals was included as a covariate in the model to compensate for variable initial concentrations among heifers. The least square mean values of FSH are reported in the results. Data not involving repeated measures were analyzed using the MIXED procedure in SAS $\vee 8.1\left(\mathrm{Y}_{\mathrm{ij}}=\mu+\mathrm{T}_{\mathrm{i}}+\right.$ $\mathrm{e}_{\mathrm{ij}}$, with notations as defined previously). Likelihood Ratio tests using the ratios of the -2 log restricted maximum likelihoods (REML) statistic of full and reduced models were performed to test the homogeneity of the variances across treatments (Littell et al. 1996). The full model allowing variances to differ among treatments was used if heterogeneity was indicated. Square root transformations were performed prior to ANOVA in many instances involving steroid concentrations in FF in which treatment variances were heterogeneous or proportional to mean values. Unless stated otherwise, data are expressed as the actual mean \pm S.E.M.

\section{Results \\ Follicular dynamics and circulating steroid hormone concentrations}

Treatments were initiated $5.6 \pm 0.1$ days after detection of oestrus when the DF1 was $10.8 \pm 0.3 \mathrm{~mm}$ in diameter (at h 12 ) and had emerged $4.1 \pm 0.2$ days previously. Concentrations of oestradiol in plasma (Fig. 1a) were elevated in the ODB NW group at $h 12$, and although declining, remained greater $(P<0.01)$ than the $C$ NW group up to $h$ 96. The increase in plasma oestradiol in the ODB NW group was associated with an immediate cessation in growth of the DF1 (Fig. 1b) and a smaller $(P<0.01)$ diameter during the plateau phase as compared with the DF1 in the C NW group. Time of emergence of a new wave of follicular development after treatment initiation for the ODB NW (d $4.8 \pm 0.3$ ) and the C NW (d $4.4 \pm 0.1$ ) groups was not different, but was more $(P<0.05)$ variable for the ODB NW treatment. Concentration of progesterone in plasma among all heifers was $1.2 \pm 0.1 \mathrm{ng} \mathrm{ml}^{-1}$ on $\mathrm{d} 0$. The subsequent rise in circulating progesterone over the next five days was evident in both treatments, but was reduced $(P<0.01)$ in the ODB NW compared with the $C$ NW group (Fig. 1c).

\section{Gonadotrophin responses}

Concentrations of FSH (Fig. 1d) were not affected by treatment, but were greater $(P<0.05)$ between $\mathrm{h} 66$ and $\mathrm{h}$ 102 than around the time ( $\mathrm{h}-12$ to 18 ) that treatment was initiated. The average maximum values were observed at h 90 and $h 96$, and the first decline $(P<0.05)$ from this peak was observed at $h$ 108. The time of peak FSH concentration was also assessed within individual animals. The average time of the $\mathrm{FSH}$ peak within individuals of the ODB NW (h $79.0 \pm 8.4$ ) and C NW (h $89.1 \pm 3.6)$ groups was similar. However, the interval from the FSH peak to emergence of a new wave of follicular development was increased $(P<0.01)$ in the ODB NW $(35.0 \pm 2.9$ hours) compared with the C NW group (17.1 $\pm 2.4 \mathrm{~h})$.

Characteristics of $\mathrm{LH}$ secretion were compared at $h$ $-12,0,24$ and 48 (Fig. 2). The frequency of LH pulses 

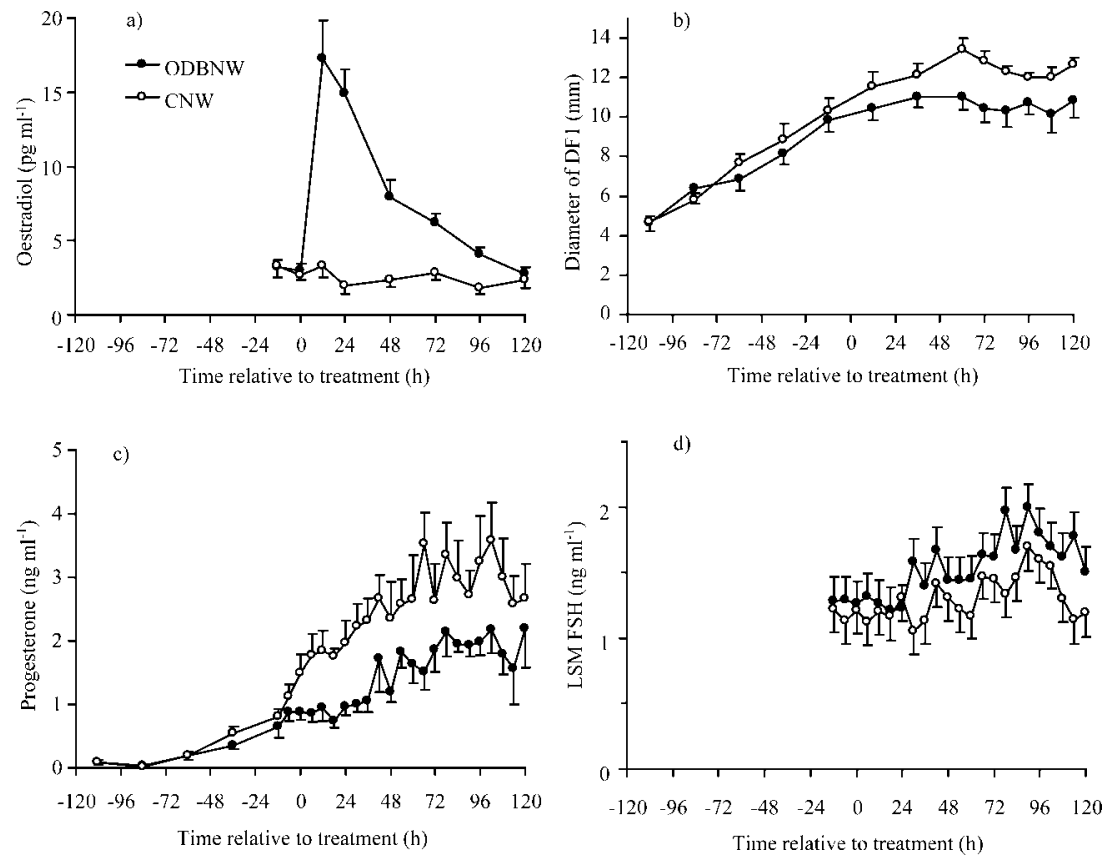

Figure 1 (a) Plasma concentrations of oestradiol, (b) diameter of the first dominant follicle (DF1), (c) plasma concentrations of progesterone and (d) least square mean (LSM) plasma concentrations of $\mathrm{FSH}$ in heifers that received $1 \mathrm{mg}$ ODB (oestradiol benzoate) i.m./500 kg BW (ODBNW; $n=7$ ) on day $5.6 \pm 0.1$ of the oestrous cycle (hour (h) 0 ) as compared with untreated controls (CNW; $n=7$ ). NW refers to the groups of heifers that were monitored through to confirmation of emergence of a new wave of follicular development. Means plotted beyond $\mathrm{h} 114$ are data from six heifers per treatment group as one heifer from each treatment had been ovariectomized before these times.
(Fig. 2a) declined $(P<0.01)$ over time but did not differ among treatments. The amplitude of the $\mathrm{LH}$ pulses was greater $(P<0.05)$ at $\mathrm{h} 24$ and $\mathrm{h} 48$ than at $\mathrm{h}-12$ and $\mathrm{h} 0$ for the C NW group (Fig. 2b), whereas pulse amplitude remained constant $(P>0.1)$ over all periods for the ODB NW group. Mean concentrations of LH (Fig. 2c) remained constant at about $0.8 \mathrm{ng} \mathrm{ml}^{-1}$ in the $\mathrm{C} \mathrm{NW}$ group. Mean values in the ODB NW were similar $(P>0.1)$ to the $C$ NW group at $\mathrm{h}-12$ and $\mathrm{h} 0$, but declined $(P<0.05)$ to less than $0.6 \mathrm{ng} \mathrm{ml}^{-1}$ at h 24 to $\mathrm{h} \mathrm{48,} \mathrm{and} \mathrm{these} \mathrm{concen-}$ trations were less $(P<0.05)$ than in controls for the equivalent time periods.

\section{Steroids in follicular fluid (FF)}

Concentrations of oestradiol in FF were reduced fivefold $(P<0.01)$ at $\mathrm{h} 36$ in the ODB as compared with the $\mathrm{C}$ group, and was equivalent to the $C$ group after a new follicular wave had emerged (Table 1). A substantial decline $(P<0.01)$ in FF oestradiol concentrations occurred between $\mathrm{h} 12$ and $\mathrm{h} 36$ in the ODB treatment group. This decline was associated with reduced $(P<0.05)$ concentrations of testosterone and androstenedione at $\mathrm{h} 36$ in the ODB treatment group as compared with control animals (Table 1). Concentrations of FF testosterone and FF androstenedione were positively correlated $\left(r^{2}=0.85\right.$; $P<0.01)$. A fivefold increase $(P<0.01)$ in FF progesterone concentration was observed in the ODB treatment group between $\mathrm{h} 36$ and after a new follicular wave had emerged. In contrast, FF progesterone concentrations in DF were not increased $(P>0.1)$ after new wave emergence in control animals (Table 1).

\section{The number of granulosa cell layers and incidence of apoptosis}

The overall average number of granulosa cell layers was reduced (treatment; $P<0.05)$ in the DF1 of ODB $(5.2 \pm 1.2)$ as compared with $C$ treatments $(8.3 \pm 1.6)$. Across treatments, the number of granulosa cell layers declined from $9.7 \pm 1.0$ at $\mathrm{h} 36$ to $3.2 \pm 0.6$ after emergence of a new follicular wave (time; $P<0.01$ ). A time-bytreatment interaction was not detected. The number of granulosa cell layers in ODB $12 \mathrm{H}$ group (Table 1) was greater $(P<0.01)$ than for the ODB NW group, and tended $(P=0.08)$ to be greater than the ODB $36 \mathrm{H}$ group. The proportion of apoptotic granulosa cells increased (time; $P<0.01)$ from $2.9 \pm 1.7 \%$ at h 36 to $25.4 \pm 4.2 \%$ after emergence of a new follicular wave in a similar $(P>0.1)$ manner for ODB and C treatments (Table 1). Photographs representing the erosion of the granulosa cell membrane and the increasing extent of apoptosis across time within the ODB-treated groups are presented in Fig. 3.

\section{Discussion}

A prerequisite for synchronizing the wavelike pattern of follicular development that occurs on the ovaries of cattle using an exogenous treatment is that the existing DF ceases to be dominant. Induction of atresia can be achieved with exogenous progesterone alone, provided that the DF has developed for an extended period under a low progestagen environment (Day \& Burke 2002). The mechanisms of progesterone-induced atresia of 'aged' DF have been reported (Manikkam \& Rajamahendran 1997). This previous study found that an acute reduction in intrafollicular aromatase activity, oestradiol content and insulin-like growth factor 

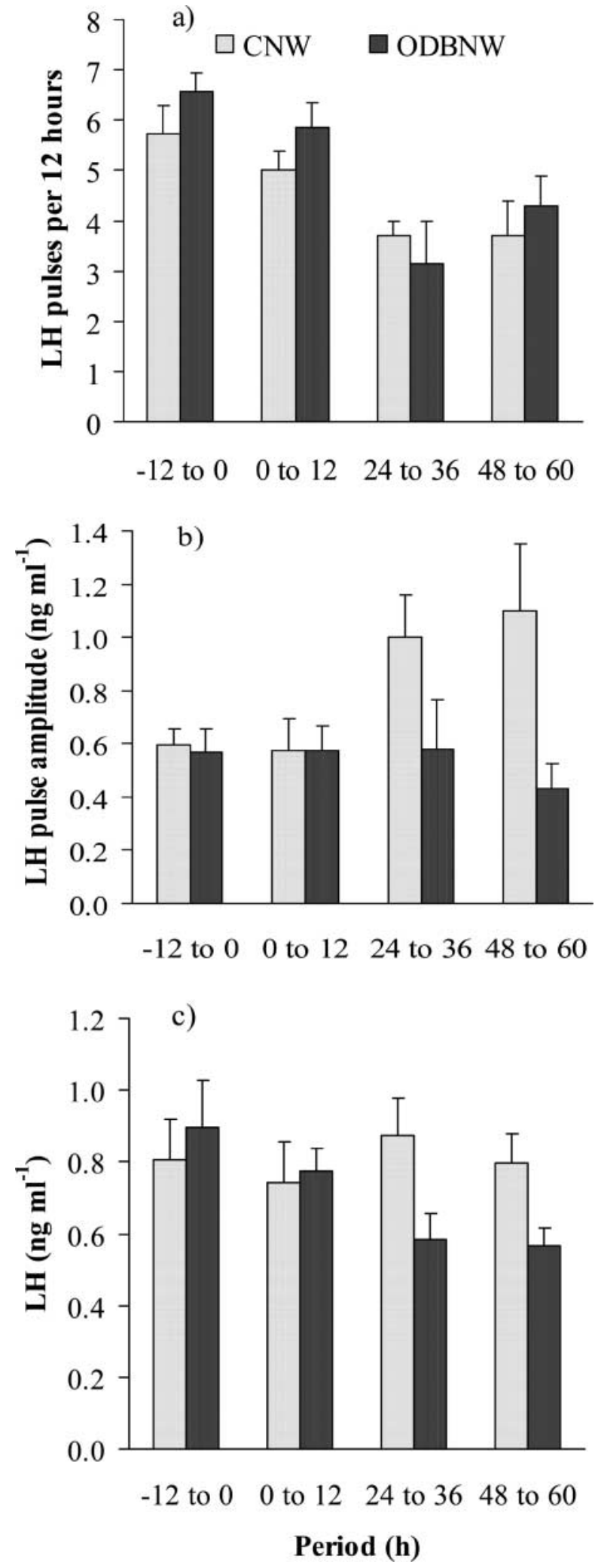

Figure 2 Frequency of LH pulses/ $12 \mathrm{~h}$ (a), amplitude of LH pulses (b) and mean concentrations of $\mathrm{LH}$ (c) during periods of $12 \mathrm{~h}$ beginning at $\mathrm{h}-12,0,24$ and 48 in heifers that received $1 \mathrm{mg}$ ODB i.m. $/ 500 \mathrm{~kg} \mathrm{BW}(\mathrm{ODBNW} ; n=7)$ on day $5.6 \pm 0.1$ of the oestrous cycle (hour (h) 0 ) as compared with untreated controls (CNW; $n=7$ ). availability were key features of induced atresia. The present study is the first to provide a detailed characterization of systemic hormone changes and intrafollicular events that occur during loss of dominance due to oestradiolinduced atresia. The key findings were that the oestrogenic function of the DF was effectively removed at $\mathrm{h} 36$ and this was associated with reduced testosterone in FF and support from $\mathrm{LH}$ in the circulation. The patterns of change in circulating concentrations of $\mathrm{FSH}$ and the timing of the emergence of a new follicular wave of development were not different between treated and control heifers. This suggests that a factor(s) other than the oestrogenic status of the DF is critically influencing the timing of new follicular development on the ovaries of cattle following oestradiol-induced atresia of the DF.

Gonadotrophins are the major survival signals for mature antral follicles (Markström et al. 2002), and reduced circulating concentrations of LH (Burke et al. 1996) and FSH (O'Rourke et al. 2000) are believed to be the primary mechanism through which exogenous oestradiol perturbs follicular development. The experimental design of the present study aimed to characterize the temporal events occurring within the DF during oestradiolinduced atresia, and the temporal relationships between gonadotrophins and follicular function. It is well established that in order for a follicle to become a mature DF, a switch from being $\mathrm{FSH}$-dependent to $\mathrm{LH}$ dependency is required (Lucy et al. 1992, Findlay et al. 1996, Gong et al. 1996, Crowe et al. 2001). A critical dependency on LH in mature DFs is further demonstrated in studies where experimentally increased LH support extended the duration of dominance well beyond normal (Sirois \& Fortune 1990, Taft et al. 1996). Maximal expression of mRNA for $\mathrm{LH}$ receptor in theca and granulosa cells is observed on about day 4 after emergence (see Bao \& Garverick 1998) and $\mathrm{LH}$ receptor density is greatest at this time in nonovulatory DFs (Ireland \& Roche 1983). In the present study, treatments were initiated when DFs were at this $\mathrm{LH}$-dependent stage of maturity. On the strength of this well-established relationship, we speculate that oestradiolinduced suppression of $\mathrm{LH}$ was the primary driver for the observed responses in the DFs after oestradiol treatment.

It is evident from the present study that the oestrogenic capacity in the DF was rapidly decreased (i.e. within $36 \mathrm{~h}$ ) following ODB treatment. The loss of oestrogenic function is considered unfavourable for continued survival of the follicle. Oestradiol promotes growth of the follicle in multiple ways (Rosenfeld et al. 2001, Schams \& Berisha 2002) and is considered an anti-apoptotic factor (Knecht et al. 1984, Billig et al. 1993, Kaipia \& Hsueh 1997, Lund et al. 1999). A direct effect of exogenous oestradiol on the DF is possible although unlikely. First, intrafollicular concentrations of oestradiol in healthy DFs are several 1000-fold greater than systemic concentrations (Ginther et al. 1997), even when considering the elevation in circulating concentrations due to treatment with ODB. Secondly, direct 

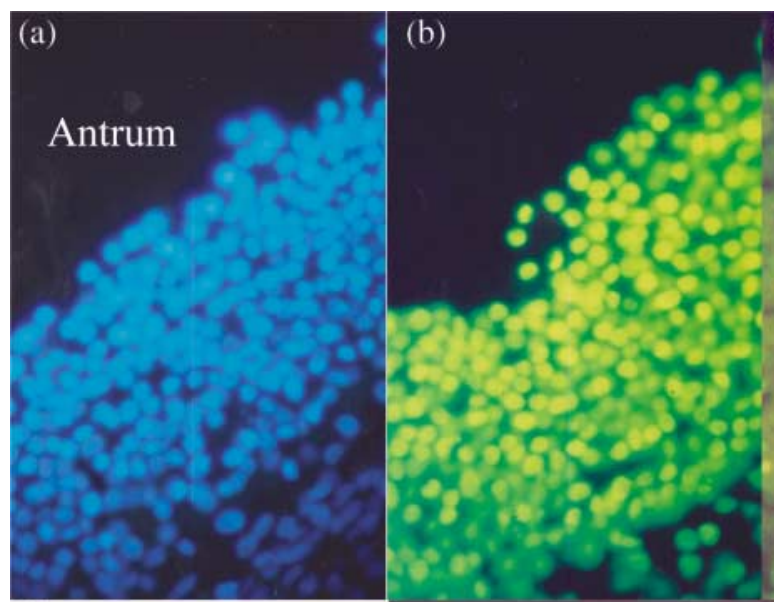

(c)

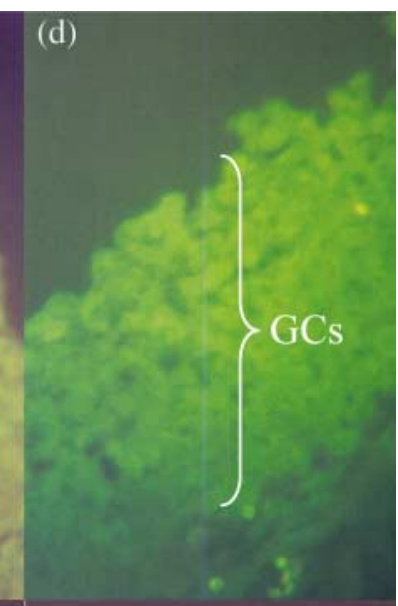

(e)

(f)

(g)

(h)
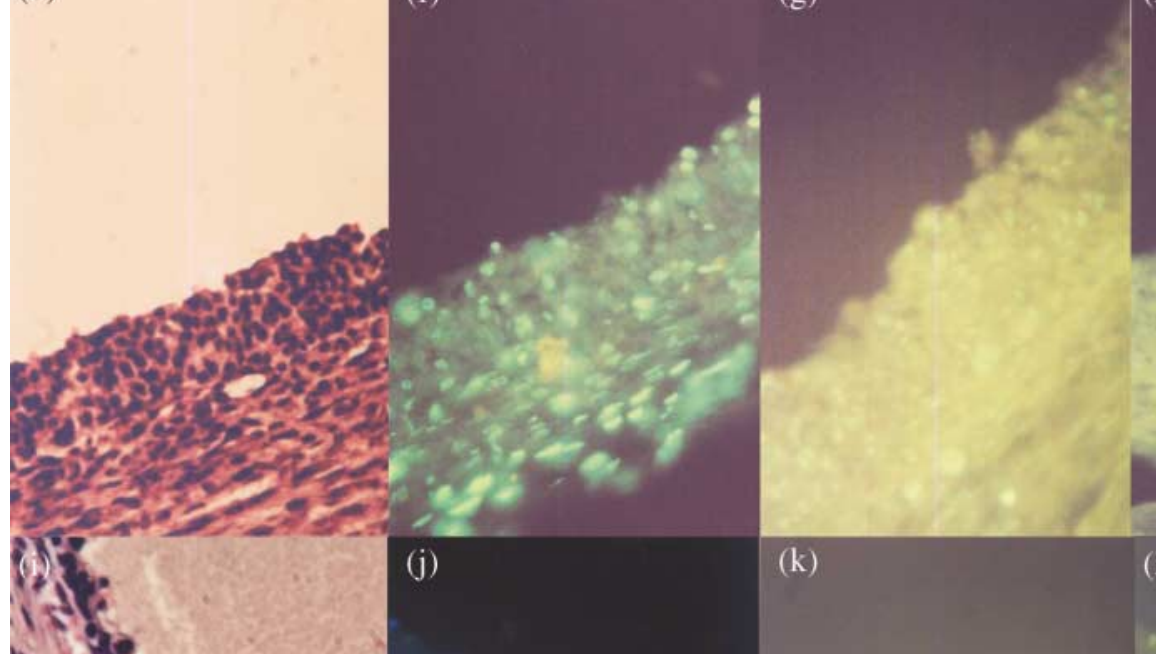

(I)
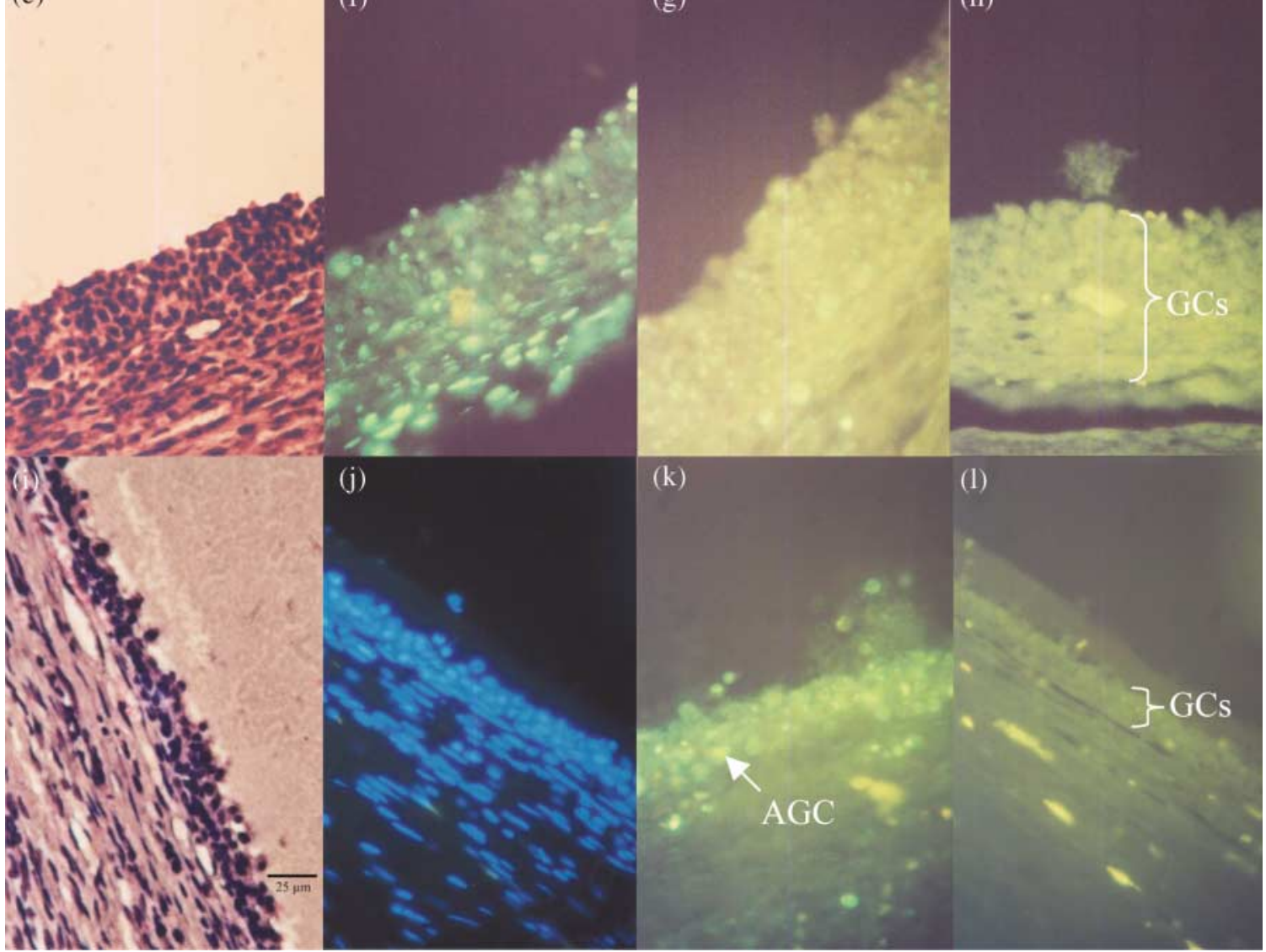

Figure 3 Representative photomicrographs of the follicular wall of first dominant follicles (DF1) in the ODB-treated groups; $12 \mathrm{H}$ ODB (a to d), $36 \mathrm{H}$ ODB (e to $\mathrm{h}$ ) and ODBNW ( $\mathrm{i}$ to l). Each row represents the same DF1. Haematoxylin and eosin (e and i), DAPI (a and j), positive control (DNase treated) TUNEL (b and f), TUNEL sample (c, g and k), negative control (TdT omitted) TUNEL (d, h and l). RBCs, red blood cells; GCs, granulosa cells; AGC, apoptic granulosa cell. Magnification $(\times 400)$ is similar for all photomicrographs (note the $25 \mu \mathrm{m}$ magnification bar in i).

placement of oestradiol into ovarian stroma adjacent to the DF did not cause atresia (Bo et al. 2000).

Concentrations of testosterone and oestradiol in FF at $h$ 36 in ODB-treated heifers were markedly reduced compared with controls. The observed reduction in androstenedione was not significant at the $95 \%$ confidence level. In agreement with other studies in cattle (Badinga et al. 1992, Lucy et al. 1992), the decrease in FF oestradiol could be explained by reduced availability of androgen substrate for aromatization. The present study provides strong evidence that the oestrogenic function of the DF1 was suppressed during ODB treatment via reduced $\mathrm{LH}$ support for thecal tissue synthesis of oestrogenic precusor steroids. However, studies in sheep (Tsonis et al. 1984), and in cattle during progesterone-induced atresia of 'persistent' DF (Manikkam \& Rajamahendran 1997), indicated 
that the decrease in FF oestradiol during atresia was primarily related to reduced aromatase activity. Further studies are required to determine how steroidogenic enzymes, such as aromatase and $17 \alpha$-hydroxylase, respond during oestradiol-induced atresia of DFs.

Follicular fluid progesterone concentrations after new follicular wave emergence were markedly greater in DF1s of ODB-treated than control heifers. The greater concentration of progesterone in atretic follicles after new wave emergence in the ODB-treated animals suggests a more advanced state of atresia compared with that in untreated controls. The latter finding is consistent with several reports showing that FF progesterone increases as follicles become atretic (Uilenbroek et al. 1980, Bodensteiner et al. 1996). The reason for an accumulation in FF progesterone during atresia could be because theca cells remain viable and continue to produce progesterone even during apoptotic destruction of the granulosa cell compartment (Fortune \& Quirk 1988, Xu et al. 1995). Thus the increase in progesterone may simply reflect an accumulation of substrate that is not converted to downstream steroids (Hubbard \& Greenwald 1981). Additionally, a recent study has suggested that the increase in FF progesterone is an important aspect of cell death and is achieved through an FSH-stimulated increase in progesterone synthesis in granulosa cells (Gross et al. 2001).

The advanced state of atresia in follicles of ODB-treated animals was further supported by reduced numbers of granulosa cell layers. The maximum number of granulosa cells is attained in bovine follicles at about $9 \mathrm{~mm}$ in diameter (Lussier et al. 1987, Fortune 1994), a smaller diameter than the DF1s in the present study. Thus, the reduction in the number of granulosa cell layers in the DF1s of ODBtreated animals indicates greater degradation of the granulosa cell compartment. The TUNEL assay procedure was able to detect the increased rate of apoptosis in the DF1s after a new wave of follicular development. The rate of apoptosis $(25 \%)$ was consistent with that in DFs undergoing progesterone-induced atresia (Manikkam \& Rajamahendran 1997). However, the TUNEL assay used in the present study failed to detect greater rates of apoptosis at any time point in ODB-treated as compared with control heifers. It is possible that the rate of apoptosis was greater in the DF1s of the ODB-treated group at time points not measured in the present study. In agreement with previous studies (Jolly et al. 1994, Manikkam \& Rajamahendran 1997, Yang \& Rajamahendran 2000), some apoptotic granulosa cells were detected even in apparently 'healthy' DFs in the present study. The appearance of an inherent basal rate of apoptosis throughout follicular development increases the likelihood that increased degeneration of the granulosa cell compartment following ODB treatment occurred without the sampling or assay procedure being sufficiently sensitive to detect such changes. Additionally, the TUNEL assay does not detect granulosa cells that are completely degraded or, in the present study, granulosa cells that are sloughed from the granulosa cell compartment into the antrum of the follicle. These alternative endpoints of cellular death were not assessed in the present study. Further studies are required to determine if apoptotic trigger signals, such as Fas ligand and Fas antigen (Porter et al. 2001), are up-regulated during the process of oestradiol-induced atresia to better establish the relative role of apoptosis during this event.

Timing of the pre-emergence increase in FSH and subsequent new follicular wave development was not different between the ODB-treated and control heifers. The second wave of follicular development normally begins on about day 10 of the oestrous cycle in heifers (Sirois \& Fortune 1988), and this timing was observed in the control group of the present study as expected. Timing of a new wave of follicular development following administration of oestradiol is typically observed three to five days later (Bo et al. 2002, Diskin et al. 2002, Day \& Burke 2002). The interval to new emergence in ODB-treated heifers of the present study was within these reported times, and consistent with our previous results following administration of $1 \mathrm{mg}$ ODB at various stages of the oestrous cycle in beef heifers (Day \& Burke 2002). As ODB treatment did not result in earlier new wave emergence, one possibility is that the DF1 continued to dominate despite a loss in estrogenic function in ODB-treated animals. This would be possible if the DF continued to secrete inhibin (Kaneko et al. 2002), which was not measured in the present study. Alternatively, ODB treatment could have exerted a direct effect on FSH to regulate emergence of the next follicular wave. We tested this possibility in another experiment by aspirating the DF1 and administering increasing doses of ODB from 0 to $4 \mathrm{mg}$ (Burke et al. 2003). This latter study clearly showed that in the absence of the DF1, ODB delays the increase in FSH and the timing of new wave emergence in a dose-dependent manner. It also demonstrated that variation in timing of the pre-emergence increase in FSH and new follicle wave emergence is dependent on clearance of oestradiol from the circulation. This may have accounted for the fact that ODB-treated heifers of the present study had a more variable timing in new emergence relative to controls. In the present study, ODB may have postponed emergence by inhibiting the pre-emergence increase in $\mathrm{FSH}$, even though the DF1 had entered an atretic state and had lost dominance. It is speculated that the timing of emergence of the second wave was influenced by peripheral oestradiol concentrations resulting from the ODB in this treatment group, whereas in the control animals, the time of emergence was a function of time of spontaneous atresia of the DF1.

In conclusion, administration of an atretogenic dose of ODB reduced concentrations of $\mathrm{LH}$ in the circulation and promoted a rapid and sustained loss in the estrogenic capacity of DFs. Erosion of the granulosa cell compartment was increased in the DF1 of ODB-treated animals, but the rate of apoptosis in granulosa cells was not increased by ODB. The extent to which ODB-induced atresia approximates the process of spontaneous atresia 
requires further clarification. This approach could serve as a useful model to better understand the mechanisms that initiate atresia and the progressive nature of this process in bovine ovarian follicles.

\section{Acknowledgements}

The authors thank Stuart Morgan, Dr Dave Grum, Allan Robison, Pam Ferrel and Dr Fran Adamski for assistance in data collection, Drs Jim Kinder and Joy Pate for serving as internal reviewers of the manuscript and Dr Normand St-Pierre for statistical support. Donation of Lutalyse (Pfizer, Kalamazoo, MI, USA) is gratefully acknowledged. Salaries and research support were provided by State and Federal funds appropriated to the Ohio Agricultural Resource Development Center (OARDC; Manuscript No. 19-04AS) and through competitive grant funds (OARDC; No. OHOAO628). The authors declare that there is no conflict of interest that would affect the impartiality of this scientific work.

\section{References}

Adams GP, Matteri RL, Kastelic JP, Ko JCH \& Ginther OJ 1992 Association between surges of follicle-stimulating hormone and the emergence of follicle waves in heifers. Journal of Reproduction and Fertility 94 177-188.

Anderson LH, McDowell CM \& Day ML 1996 Progesterone-induced puberty and secretion of luteinizing hormone in heifers. Biology of Reproduction 54 1025-1031.

Badinga L, Driancourt MA, Savio JD, Wolfenson D, Drost M, de la Sota RL \& Thatcher WW 1992 Endocrine and ovarian responses associated with the first-wave dominant follicle in cattle. Biology of Reproduction 47 871-883.

Bao B \& Garverick HA 1998 Expression of steroidogenic enzyme and gonadotropin receptor genes in bovine follicles during ovarian follicular waves: a review. Journal of Animal Science $\mathbf{7 6}$ 1903-1921.

Bergfelt DR, Lightfoot KC \& Adams GP 1994 Ovarian synchronization following ultrasound-guided transvaginal follicle ablation in heifers. Theriogenology 42 895-907.

Billig H, Furuta I \& Hsueh AJ 1993 Estrogens inhibit and androgens enhance ovarian granulosa cell apoptosis. Endocrinology 133 2204-2212.

Bo GA, Adams GP, Caccia M, Martinez M, Pierson RA \& Mapletoft RJ 1995 Ovarian follicluar wave emergence after treatment with progestogen and estradiol in cattle. Animal Reproduction Science 39 193-204.

Bo GA, Bergfelt DR, Brogliatti GM, Pierson RA, Adams GP \& Mapletoft RJ 2000 Local versus systemic effects of exogenous estradiol-17 $\beta$ on ovarian follicular dynamics in heifers with progestogen implants. Animal Reproduction Science 59 141-157.

Bo GA, Baruselli PS, Moreno D, Cutaia L, Caccia M, Tribulo R, Tribulo H \& Mapletoft RJ 2002 The control of follicular wave development for self-appointed embryo transfer programs in cattle. Theriogenology 57 53-72.

Bodensteiner KJ, Wiltbank MC, Bergfelt DR \& Ginther OJ 1996 Alterations in follicular estradiol and gonadotropin receptors during development of bovine antral follicles. Theriogenology 45 499-512.

Burke CR, Macmillan KL \& Boland MP 1996 Oestradiol potentiates a prolonged progesterone-induced suppression of $\mathrm{LH}$ release in ovariectomised cows. Animal Reproduction Science 45 13-28.

Burke CR, Mussard ML, Gasser CL, Grum DE \& Day ML 2003 Estradiol benzoate delays new follicular wave emergence in a dose-dependent manner after ablation of the dominant ovarian follicle in cattle. Theriogenology 60 647-658.

Crowe MA, Kelly P, Driancourt MA, Boland MP, \& Roche JF 2001 Effects of follicle-stimulating hormone with and without luteinizing hormone on serum hormone concentrations, follicle growth, and intrafollicular estradiol and aromatase activity in gonadotropinreleasing hormone-immunized heifers. Biology of Reproduction 64 368-374.

Day ML \& Burke CR 2002 Management of follicular growth with progesterone and estradiol within progestin-based estrous synchrony systems. In Factors Affecting Calf Crop, pp 101-117. Eds MJ Fields, RS Sand \& JV Yelich. Boca Raton, Florida: CRC Press.

Diskin MG, Austin EJ \& Roche JF 2002 Exogenous hormonal manipulation of ovarian activity in cattle. Domestic Animal Endocrinology 23 211-228.

Dyer RM, Bishop MD \& Day ML 1990 Exogenous estradiol reduces inhibition of luteinizing hormone by estradiol in prepubertal heifers. Biology of Reproduction 42 755-761.

Findlay JK, Drummond AE \& Fry RC 1996 Intragonadal regulation of follicular development and ovulation. Animal Reproduction Science 42 321-331.

Fortune JE 1994 Ovarian follicular growth and development in mammals. Biology of Reproduction 50 225-232.

Fortune JE \& Quirk SM 1988 Regulation of steroidogenesis in bovine preovulatory follicles. Journal of Animal Science 66 (Supp 2) 1-8.

Gavrieli Y, Sherman Y \& Bensasson AA 1992 Identification of programmed cell death in situ via specific labeling of nuclear DNA fragmentation. Journal of Cell Biology 119 493-501.

Ginther OJ, Kot K, Kulick LJ \& Wiltbank MC 1997 Sampling follicular fluid without altering follicular status in cattle: oestradiol concentrations early in the follicular wave. Journal of Reproduction and Fertility 109 181-186.

Gong JG, Campbell TA, Bramley TA, Gutierrez CG, Peters AR \& Webb R 1996 Suppression in the secretion of follicle-stimulating hormone and luteinizing hormone, and ovarian follicular development in heifers continuously infused with a gonadotropin-releasing hormone agonist. Biology of Reproduction 55 68-74.

Goodman RL \& Karsch FJ 1980 Pulsatile secretion of luteinizing hormone: differential suppression by ovarian steroids. Endocrinology 107 1286-1290.

Gross SA, Newton JM \& Hughes FM 2001 Decreased intracellular potassium levels underlie increased progesterone synthesis during ovarian follicular atresia. Biology of Reproduction 64 1755-1760.

Hubbard CJ \& Greenwald GS 1981 Changes in DNA, cyclic nucleotides and steroids during induced follicular atresia in the hamster. Journal of Reproduction and Fertility 63 455-461.

Ireland JJ \& Roche JF 1983 Development of nonovulatory antral follicles in heifers: Changes in steroids in follicular fluid and receptors for gonadotropins. Endocinology 112 150-156.

Jolly PD, Tisdall DJ, Heath DA, Lun S \& McNatty KP 1994 Apoptosis in bovine granulosa cells in relation to steroid synthesis, cyclic adenosine $3^{\prime}, 5^{\prime}$-monophosphate response to follicle stimulating hormone and luteinizing hormone, and follicular atresia. Biology of Reproduction 51 934-944.

Kaipia A \& Hsueh AJW 1997 Regulation of ovarian follicle atresia. Annual Reviews of Physiology 59 349-363.

Kaneko H, Noguchi J, Kikuchi K, Todoroki J \& Hasegawa Y 2002 Alterations in peripheral concentrations of inhibin $\mathrm{A}$ in cattle studied using a time-resolved immunofluorometric assay: Relationship with estradiol and follicle-stimulating hormone in various reproductive conditions. Biology of Reproduction 67 38-45.

Kesler DJ, Garverick HA, Youngquist RS, Elmore RG \& Bierschwal CJ 1977 Effect of days postpartum and endogenous reproductive hormones on $\mathrm{GnRH}$-induced LH release in dairy cows. Journal of Animal Science 46 797-803.

Knecht M, Darbon JM, Ranta JM, Baukal AJ \& Catt KJ 1984 Estrogens enhance the adenosine $3^{\prime}, 5^{\prime}$-monophosphate-mediated induction of follicle-stimulating hormone and luteinizing hormone receptors in rat granulosa cells. Endocrinology 115 41-49. 
Littell RC, Milliken GA, Stroup WW \& Wolfinger RD 1996 In SAS System for Mixed Models. Cary, NC: SAS Institute Inc.

Lucy MC, Savio JD, Badinga L, De La Sota RL \& Thatcher WW 1992 Factors that affect ovarian follicular dynamics in cattle. Journal of Animal Science 70 3615-3626.

Lund SA, Murdoch J, Van Kirk EA \& Murdoch WJ 1999 Mitogenic and antioxidant mechanisms of estradiol action in preovulatory ovine follicles: relevance to luteal function. Biology of Reproduction 61 388-392.

Lussier JG, Matton P \& Dufour JJ 1987 Growth rates of follicles in the ovary of the cow. Journal of Reproduction and Fertility 81 301-307.

McNatty KP, Heath DA, Henderson KM, Lun S, Hurst PR, Ellis LM, Montgomery GW, Morrison L \& Thurley DC 1984 Some aspects of thecal and granulosa cell function during follicular development in the bovine ovary. Journal of Reproduction and Fertility $\mathbf{7 2}$ 39-53.

Manikkam M \& Rajamahendran R 1997 Progesterone-induced atresia of the proestrous dominant follicle in the bovine ovary: changes in diameter, insulin-like growth factor system, aromatase activity, steroid hormones, and apoptotic index. Biology of Reproduction 57 580-587.

Markström E, Svensson EC, Shao R, Svanberg B \& Billig H 2002 Survival factors regulating ovarian apoptosis - dependence on follicle differentiation. Reproduction 123 23-30.

O'Rourke M, Diskin M, Greenan JM \& Roche JR 2000 The effect of dose and route of oestradiol benzoate administration on plasma concentrations of oestradiol and FSH in long-term ovariectomized heifers. Animal Reproduction Science 59 1-12.

Porter DA, Harman RM, Cowan RG \& Quirk SM 2001 Relationship of Fas ligand expression and atresia during bovine follicle development. Biology of Reproduction 121 561-566.

Price CA, Carrière PD, Bhatia B \& Groome NP 1995 A comparison of hormonal and histological changes during follicular growth, as measured by ultrasonography, in cattle. Journal of Reproduction and Fertility 103 63-68.

Rosenfeld CS, Wagner JS, Roberts RM \& Lubahn DB 2001 Intraovarian actions of oestrogen. Reproduction 122 215-226.

SAS Institute Inc. 1996 In SAS/STAT User's Guide. Cary, NC: SAS Institute Inc.

Schams D \& Berisha B 2002 Steroids as local regulators of ovarian activity in domestic animals. Domestic Animal Endocrinology 23 $53-65$.
Sirois J \& Fortune JE 1990 Lengthening the bovine estrous cycle with low levels of exogenous progesterone: A model for studying ovarian follicular dominance. Endocrinology 127 916-925.

Sirois J \& Fortune JE 1988 Ovarian follicular dynamics during the estrous cycle in heifers monitored by real-time ultrasonography. Biology of Reproduction 39 308-317.

Taft R, Ahmad N \& Inskeep EK 1996 Exogenous pulses of luteinizing hormone cause persistence of the largest bovine ovarian follicle. Journal of Animal Science 74 2985-2991.

Thundathil J, Kastelic JP \& Mapletoft RJ 1998 The effect of estradiol cypionate (ECP) on ovarian follicular development and ovulation in dairy cattle. Canadian Journal of Veterinary Research $62314-316$

Tsonis CG, Carson RS \& Findlay JK 1984 Relationships between aromatase activity, follicular fluid oestradiol-17ß and testosterone concentrations, and diameter and atresia of individual ovine follicles. Journal of Reproduction and Fertility 72 153-163.

Uilenbroek JTJ, Woutersen PJA \& van der Schoot P 1980 Atresia of preovulatory follicles: gonadotropin binding and steroidogenic activity. Biology of Reproduction 23 219-229.

Wolfe MW, Roberson MS, Stumpf TT, Kittock RJ \& Kinder JE 1992 Circulating concentrations and pattern of luteinizing hormone and follicle-stimulating hormone in circulation are changed by the circulating concentration of $17 \beta$-estradiol in the bovine male and female. Journal of Animal Science 70 248-253.

Wyllie AH 1980 Glucocorticoid-induced thermocyte apoptosis is associated with endogenous endonuclease activation. Nature 339 $625-626$.

Xu ZZ, Garverick HA, Smith GW, Smith MF, Hamilton SA \& Youngquist RS 1995 Expression of messenger RNA encoding cytochrome P450 side chain cleavage, cytochrome P450 17 $\alpha$-hydroxylase and cytochrome P450 aromatase in bovine follicles during the first follicular wave. Endocrinology 136 981-989.

Yang MY \& Rajamahendran R 2000 Involvement of apoptosis in the atresia of non-ovulatory dominant follicle during the bovine estrous cycle. Biology of Reproduction 63 1313-1321.

Received 16 June 2004

First decision 7 September 2004

Revised manuscript received 8 February 2005

Accepted 18 February 2005 